\title{
Effect of Sulphur Nutrient and Moisture Regimes on Growth and Productivity of Wheat (Triticum aestivum L.) Varieties
}

\author{
Nareshmani Pandey, Sanjay Kumar ${ }^{*}$, Ghanshyam Singh and R.A. Singh \\ Department of agronomy, NDUAT, Kumarganj, Faizabad 224229 UP, India \\ *Corresponding author
}

Keywords

Wheat, sulphur nutrient, IW/CPE ratio, Varieties, Growth, Yield.

Article Info

Accepted:

10 July 2017

Available Online:

10 September 2017

\section{A B S T R A C T}

The field experiment was conducted at Agronomy Research Farm of Narendra Deva University of Agriculture and Technology, Kumarganj, Faizabad (U.P.) during Rabi season of 2013-14 and 2014-15.The experiment was carried out in split plot design with three replications. with 24 treatment combinations, comprised of four irrigation levels (a) $\mathrm{I}_{1} ; 0.6 \mathrm{IW} / \mathrm{CPE}$ ratio (b) $\mathrm{I}_{2} ; 0.8 \mathrm{IW} / \mathrm{CPE}$ ratio (c) $\mathrm{I}_{3} ; 1.0 \mathrm{IW} / \mathrm{CPE}$ ratio and (c) $\mathrm{I}_{4} ; 1.2$ IW/CPE ratio with two varieties namely PBW 343 and PBW 502 and three sulphur levels (a) Control (b) $20 \mathrm{~kg} / \mathrm{ha} \mathrm{(c)} 40 \mathrm{~kg} / \mathrm{ha}$. The growth attributes plant height, no of shoot $\mathrm{m}^{2}$ and leaf area index was significantly superior $1.2 \mathrm{IW} / \mathrm{CPE}$ ratio with PBW 502 variety at all growth stages except 30 days after sowing.PBW-502 (V2) wheat cultivar recorded significantly higher yield of crop over PBW-343 (V1). Moisture regime 1.0 IW/CPE (I3) has been found most suitable for wheat production. The optimum dose of sulphur has been found as $20 \mathrm{~kg} / \mathrm{ha}$ (S2) for wheat production. Wheat cultivar, PBW-502 (V2) recorded the significantly high uptake of NPK and sulphur under 1.0 IW/CPE moisture regime (I3) with $20 \mathrm{~kg} / \mathrm{sulphur}$ dose $\mathrm{kg} / \mathrm{ha}$. (S2). Wheat cultivar PBW-502 (V2) accrued the maximum net return with B: C ratio of 2.65 and 2.47 under 1.0 IW/CPE moisture regime (I3) with $20 \mathrm{~kg}$ / ha. Sulphur dose (S2) during the year 2013-14 and 2014-15, respectively.

\section{Introduction}

Wheat (Triticum aestivum L.) is the most important crop of the world. It belongs to Poaceae family. In India, about $90 \%$ of the total wheat production is contributed by northern states. Among them, Uttar Pradesh ranks first with respect to area $(9.734 \mathrm{mha})$ and production $(30.30 \mathrm{mt})$ but the productivity is much lower $\left(3.113 \mathrm{t} \mathrm{ha}^{-1}\right)$ than Punjab with $4.724 \mathrm{t} \mathrm{ha}^{-1}$ (Anonymous, 2013). Fertility status occupies a predominant place in the growth and development of the plant. An insufficient sulphur supply can affect the yield and quality of wheat as to sulphur is required for protein and enzyme synthesis as well. It is a constituent of the amino acids, methionine and cystein. The maximum plant height, number of shoot $\mathrm{m}^{-2}$, LAI and dry matter accumulation was recorded higher with $20 \mathrm{~kg}$ sulphur /ha which, significant difference over control during was recorded by Fazal and Sisodia (1989); Liu et al., (2002). Grain yield and straw yield was also significantly influenced by this sulphur level. Similar result was found by Chaudhary et al., (2003); Jasim (2011); Sidudinis and Lazauskas (2012).

Efficient input management along with varietal improvement is the basic aspects that can help in achieving the sufficient 
production but also enhances the water productivity; it must achieve the water economy such that the demand of climate is balanced by the supply, available to it. Since water is very scare and costly input, so it must be used very judiciously by adopting an appropriate technique i.e. IW/CPE ratio or critical stages. Limon et al., (2000) reported that highest water use efficiency (WUE) 11.3 $\mathrm{kg} / \mathrm{ha} \mathrm{mm}$ and Harveer et al., (2013)has reported that the application of irrigation water at IW: CPE 1.2 proved to be optimum for exploiting the full production potential of wheat cultivar PBW-343 and also Ashok Kumar et al., (1995) was obserbed that the wheat cultivar. HD 2285 with IW: CPE ratio of 1.2 recorded the highest grain yield of 3.65 tha.

\section{Materials and Methods}

The field experiment was conducted at Agronomy Research Farm of Narendra Deva University of Agriculture and Technology Kumarganj, Faizabad (U.P.) during rabi season of 2013-14 and 2014-15. The farm is located $42 \mathrm{~km}$ away from Faizabad city on Faizabad- Raebareily road at $26.47^{\circ} \mathrm{N}$ latitude and $82.12^{\circ} \mathrm{E}$ longitude and about 113 metres above the mean sea level. The treatment was carried out with 24 treatment combination formed with four irrigation levels, two varieties and three sulphur levels, in wheat which were allocated in split plot design with three replications. The four irrigation levels (a) $\mathrm{I}_{1} ; 0.6 \mathrm{IW} / \mathrm{CPE}$ ratio (b) $\mathrm{I}_{2} ; 0.8 \mathrm{IW} / \mathrm{CPE}$ ratio (c) $\mathrm{I}_{3} ; 1.0 \mathrm{IW} / \mathrm{CPE}$ ratio and (c) $\mathrm{I}_{4} ; 1.2$ IW/CPE ratio with two varieties namely PBW 343 and PBW 502 and three sulphur levels (a) Control (b) $20 \mathrm{~kg} / \mathrm{ha} \mathrm{(c)} 40 \mathrm{~kg} / \mathrm{ha}$.

The seed rate used was $100 \mathrm{~kg} / \mathrm{ha}$ the crop was fertilised with an uniform dose of $60 \mathrm{~kg}$ $\mathrm{P}_{2} \mathrm{O}_{5} /$ ha through single super phosphate, 40 $\mathrm{kg} \mathrm{K}_{2} \mathrm{O} /$ ha through muriate of potash and half dose of the Nitrogen through urea were applied as a basal dose while the remaining nitrogen was applied in two equal split doses at tillering and panicle initiation stages of crop growth. Irrigation was provided as per irrigation scheduling time. The number of shoots were counted at 30,60, 90 DAS and at harvest by placing quadrate at three places in each plot and the plants which come within the quadrate were averaged out to express shoots per square meter Number of effective tillers (ear heads) were counted before harvesting from marked area of one square meter, Total number of spikelets from five selected spikes was counted and average values were recorded.From the individual plot the crop of net plot area was harvested. After air $\mathrm{d}$ harvesting and seed were cleaned. The final seed weight was recorded in $\mathrm{kg}$ per plot and converted in to t/ha.

\section{Results and Discussion}

The data pertaining to different moisture regimes and varieties, plant growth and yield given in table 1 reveal that the growth and yield of wheat was affected by moisture regimes.

\section{Effect on crop growth}

The maximum plant height was recorded with 1.2 IW/CPE with PBW 502 at all growth stages of crop, except 30 DAS, which were significantly superior over to 0.6 and 0.8 IW/CPE ratio. The effect of moisture level (I4) on number of shoots m-2 at 60 DAS, 90 DAS and at harvest was found significant over $\mathrm{I}_{1}$ moisture level and was at par with moisture regimes I3 (1.0 IW/CPE ratio). I4 (1.2 IW/CPE ratio) recorded the higher number of shoots m-2 (395.84 and 413.08 during the 2013-14 and 2014-15, respectively) at 90 DAS and leaf area index also significantly influenced by moisture regime at 60 and 90 DAS. Significantly higher leaf area index was observed with 1.2 IW/CPE ratio. In the early stage of crop growth, various moisture regimes could not 
produce significant changes in plant height by affected significantly at later stage. This might be due to start of different treatment at 60 DAS. Increase in plant height at higher level of moisture regime has been positively due to maintenance of constant water supply to the plants, which maintained various metabolic processes. Reported by Yadav and Verma (1991), Bandyopadhyay (1997), Rehman et al., (2000).

Varieties differences in plant height, number of shoot $\mathrm{m}^{-2}$, and leaf area index was recorded significantly with variety PBW 502 at all the growth stage of crops while differences at 30 DAS was recorded non-significant. Variety PBW 502 recorded highest plant height at harvest which was 7.02 and $8.4 \%$ higher as compared to the variety PBW 343 and an increase of 6.89 and 7.29, 5.17 and 8.33, per cent was recorded in LAI at 60 and 90 DAS in the variety PBW 502 over PBW 343 during the year 2013-14 and 2014-15, respectively. PBW 502 recorded significantly higher no of effective tillers $\mathrm{m}-2$ (278 and 283) as compared to PBW 343 (262 and 266) and also the maximum number of grains/spike was recorded with variety PBW 502 (41.00 and 42.00) compared significantly higher to variety PBW 343 (40.00 and 41.00), which was as maximum grain yield was recorded with variety PBW $502 \quad(4.72$ and 4.80 t/ha).The variation in growth development and yield might also be probably due to their characteristics. Variation in plant growth, development and yield of among varieties might also be probably due to their genetic characters. Similar finding in respect to varieties is reported by Brijkishor (1998).

The plant height increased with increasing age of crop and it attained its maximum value at harvest stage. At all the stages of crop growth, plant height was significantly higher in case of $S_{2}(20 \mathrm{~kg} / \mathrm{ha})$ sulphur application with PBW 502 at all growth stages of crop, except 30 days after sowing, The maximum plant height, number of shoot $\mathrm{m}^{-2}$ and leaf area index was recorded higher with $20 \mathrm{~kg}$ sulphur /ha, which was showed significant difference over control during both the year of study. Increase in growth with sulphur fertilization was recorded by Fazal and Sisodia (1989); Liu et al., (2002). Application of sulphur increase leaf area, tillering number of grain per ear and 1000 seed weight (yield attributes) was recorded significantly higher with $20 \mathrm{~kg}$ $\mathrm{S} /$ ha application over the control during both the years. Grain yield and straw yield was also significantly influenced by sulphur level. Similar result was found by Chaudhary et al., (2003); Jasim (2011); Sidudinis and Lazauskas (2012).

\section{Effect on yield}

Yield attributes which determined yield, is the resultant of the vegetative development of the plant. All the attributes of yield viz., effective tillers, number of grains per spike, and 1000grain weight $(\mathrm{g})$ were influenced significantly due to different moisture regime. Those were recorded maximum under 1.2 IW/CPE ratio followed by 1.0 IW/CPE. Owing to favourable vegetative growth and development because it received adequate moisture during entire period of growth. Under adequate moisture, the plant height, leaf area index were highest which contributed to highest yield attributes thereby increasing photosynthetic activity of leaves. Besides increased translocation of photosynthates from source to sink under wettest condition through higher uptake of potassium led more yield attributes. Minimum yield attributes were recorded with 0.6 IW/CPE ratio, because plant were unable to extract more water and nutrients under moisture deficit condition which resulted in poor growth and yield attributes during both the years of study. This result is close proximity to those obtained by Khola et al., (1989); Dubey and Sharma (1996); Bandyopadhyay (1997); Khatri et al., (2001) (Table 2). 
Table.1 Effect of sulphur nutrient and moisture regimes on plant height $(\mathrm{cm})$, Number of shoots $\left(\mathrm{m}^{-2}\right)$ and

Leaf Area Index (LAI) of wheat varieties

\begin{tabular}{|c|c|c|c|c|c|c|c|c|c|c|c|c|c|c|c|c|c|c|c|c|}
\hline \multirow[t]{3}{*}{ Treatments } & \multicolumn{8}{|c|}{ Plant height $(\mathrm{cm})$} & \multicolumn{8}{|c|}{ Number of shoots $\left(\mathrm{m}^{-2}\right)$} & \multicolumn{4}{|c|}{ Leaf area index (LAI) } \\
\hline & \multicolumn{2}{|c|}{$30 \mathrm{DAS}$} & \multicolumn{2}{|c|}{60 DAS } & \multicolumn{2}{|c|}{90 DAS } & \multicolumn{2}{|c|}{ At harvest } & \multicolumn{2}{|c|}{30 DAS } & \multicolumn{2}{|l|}{60 DAS } & \multicolumn{2}{|l|}{90 DAS } & \multicolumn{2}{|c|}{ At harvest } & \multicolumn{2}{|c|}{60 DAS } & \multicolumn{2}{|l|}{90 DAS } \\
\hline & $\begin{array}{l}2013- \\
14\end{array}$ & $\begin{array}{l}2014- \\
15\end{array}$ & $\begin{array}{l}2013- \\
14\end{array}$ & $\begin{array}{l}\text { 2014- } \\
15\end{array}$ & $\begin{array}{l}2013- \\
14\end{array}$ & $\begin{array}{l}2014- \\
15\end{array}$ & $\begin{array}{l}2013- \\
14\end{array}$ & $\begin{array}{l}\text { 2014- } \\
15\end{array}$ & $\begin{array}{l}2013- \\
14\end{array}$ & $\begin{array}{l}\text { 2014- } \\
15\end{array}$ & $\begin{array}{l}2013- \\
14\end{array}$ & $\begin{array}{l}2014- \\
15\end{array}$ & $\begin{array}{l}2013- \\
14\end{array}$ & $\begin{array}{l}2014- \\
15\end{array}$ & $\begin{array}{l}2013- \\
14\end{array}$ & $\begin{array}{l}2014- \\
15\end{array}$ & $\begin{array}{l}2013- \\
14\end{array}$ & $\begin{array}{l}2014- \\
15\end{array}$ & $\begin{array}{l}2013- \\
14\end{array}$ & 2014-15 \\
\hline \multicolumn{21}{|c|}{ Moisture regimes (IW/CPE Ratio) } \\
\hline 0.6 & 20.37 & 20.31 & 45.92 & 46.69 & 76.36 & 77.64 & 73.58 & 74.82 & 119.04 & 118.69 & 300.23 & 305.29 & 337.44 & 343.12 & 310.17 & 315.39 & 3.40 & 3.45 & 4.05 & 4.11 \\
\hline 0.8 & 20.42 & 20.36 & 48.08 & 48.91 & 79.94 & 81.33 & 77.04 & 78.38 & 119.35 & 119.01 & 314.34 & 319.78 & 353.30 & 359.42 & 324.74 & 330.37 & 3.56 & 3.62 & 4.24 & 4.31 \\
\hline 1.0 & 20.66 & 20.58 & 50.49 & 51.32 & 83.96 & 85.34 & 80.92 & 82.24 & 120.79 & 120.29 & 330.15 & 335.56 & 371.07 & 377.14 & 341.08 & 346.67 & 3.73 & 3.80 & 4.45 & 4.52 \\
\hline 1.2 & 21.61 & 22.26 & 52.51 & 53.27 & 87.32 & 90.85 & 84.15 & 87.56 & 126.34 & 130.10 & 343.35 & 357.23 & 395.84 & 413.08 & 363.85 & 379.70 & 3.88 & 3.94 & 4.75 & 4.95 \\
\hline SEm \pm & 0.48 & 0.51 & 0.77 & 0.79 & 1.21 & 1.97 & 1.17 & 1.90 & 2.52 & 2.72 & 4.75 & 7.74 & 7.71 & 8.45 & 7.17 & 7.89 & 0.05 & 0.05 & 0.09 & 0.10 \\
\hline CD at $5 \%$ & N.S & N.S & 2.68 & 2.72 & 4.18 & 6.81 & 4.03 & 6.56 & N.S & N.S & 16.45 & 26.77 & 26.67 & 29.25 & 24.79 & 27.29 & 0.19 & 0.19 & 0.32 & 0.36 \\
\hline \multicolumn{21}{|l|}{ Variety } \\
\hline PBW-343 & 20.69 & 20.80 & 47.46 & 48.16 & 78.92 & 80.08 & 76.05 & 77.17 & 120.96 & 121.55 & 310.30 & 314.88 & 348.76 & 353.91 & 320.57 & 325.31 & 3.51 & 3.56 & 4.18 & 4.24 \\
\hline PBW-502 & 20.84 & 20.96 & 51.04 & 51.94 & 84.88 & 87.50 & 81.80 & 84.32 & 121.80 & 122.49 & 333.73 & 344.05 & 380.06 & 392.48 & 349.35 & 360.76 & 3.77 & 3.84 & 4.56 & 4.71 \\
\hline SEm \pm & 0.32 & 0.32 & 0.92 & 0.94 & 1.19 & 1.27 & 1.14 & 1.23 & 1.82 & 1.79 & 4.66 & 5.00 & 5.39 & 5.43 & 5.14 & 5.18 & 0.05 & 0.05 & 0.07 & 0.07 \\
\hline $\mathrm{CD}$ at $5 \%$ & N.S & N.S & 3.01 & 3.05 & 3.86 & 4.15 & 3.72 & 4.00 & N.S & N.S & 15.20 & 16.31 & 17.58 & 17.71 & 16.74 & 16.89 & 0.17 & 0.17 & 0.22 & 0.22 \\
\hline \multicolumn{21}{|c|}{ Sulphur level kg/ha } \\
\hline 0 & 20.35 & 20.29 & 47.17 & 47.90 & 78.43 & 79.66 & 75.59 & 76.77 & 118.96 & 118.62 & 308.41 & 313.22 & 346.63 & 352.04 & 318.62 & 323.59 & 308.41 & 313.22 & 346.63 & 352.04 \\
\hline 20 & 21.29 & 21.81 & 50.63 & 51.51 & 84.19 & 87.35 & 81.13 & 84.18 & 124.45 & 127.46 & 331.02 & 343.48 & 379.50 & 394.73 & 348.83 & 362.83 & 331.02 & 343.48 & 379.50 & 394.73 \\
\hline 40 & 20.66 & 20.53 & 49.96 & 50.73 & 83.07 & 84.36 & 80.05 & 81.30 & 120.73 & 119.98 & 326.62 & 331.70 & 367.11 & 372.81 & 337.44 & 342.68 & 326.62 & 331.70 & 367.11 & 372.81 \\
\hline S.Em \pm & 0.45 & 0.48 & 0.84 & 0.86 & 1.07 & 1.86 & 1.03 & 1.79 & 2.78 & 2.97 & 4.19 & 7.32 & 8.67 & 9.38 & 8.25 & 8.89 & 4.19 & 7.32 & 8.67 & 9.38 \\
\hline $\mathrm{CD}$ at $5 \%$ & N.S & N.S & 2.43 & 2.47 & 3.07 & 5.36 & 2.96 & 5.17 & N.S & N.S & 12.07 & 21.09 & 24.98 & 27.02 & 23.76 & 25.60 & 12.07 & 21.09 & 24.98 & 27.02 \\
\hline
\end{tabular}

Table.2 Effect of sulphur nutrient and moisture regimes on yield attributes and yield of wheat varieties

\begin{tabular}{|c|c|c|c|c|c|c|c|c|c|c|}
\hline \multirow{2}{*}{ Treatments } & \multicolumn{2}{|c|}{ Effective tillers $\mathrm{m}^{-2}$} & \multicolumn{2}{|c|}{ Number of grains spike $^{-1}$} & \multicolumn{2}{|c|}{ Test weight (g) } & \multicolumn{2}{|c|}{ Grain yield (t/ha) } & \multicolumn{2}{|c|}{ Straw yield } \\
\hline & 2013-14 & $2014-15$ & 2013-14 & 2014-15 & $2013-14$ & 2014-15 & 2013-14 & $2014-15$ & $2013-14$ & 2014-15 \\
\hline \multicolumn{11}{|c|}{ Moisture regimes (IW/CPE Ratio) } \\
\hline 0.6 & 224.80 & 228.59 & 37.75 & 38.38 & 34.46 & 34.37 & 3.81 & 3.87 & 5.79 & 5.89 \\
\hline 0.8 & 263.93 & 268.52 & 40.19 & 40.88 & 36.69 & 36.59 & 4.47 & 4.55 & 6.81 & 6.93 \\
\hline 1.0 & 291.25 & 296.02 & 42.63 & 43.33 & 38.93 & 38.77 & 4.93 & 5.02 & 7.50 & 7.62 \\
\hline 1.2 & 301.71 & 306.05 & 44.73 & 45.37 & 40.84 & 40.89 & 5.11 & 5.19 & 7.72 & 7.83 \\
\hline SEm \pm & 3.83 & 5.26 & 0.87 & 0.83 & 0.80 & 0.75 & 0.65 & 0.89 & 0.65 & 1.01 \\
\hline CD at $5 \%$ & 13.27 & 18.19 & 3.02 & 2.88 & 2.76 & 2.59 & 2.25 & 3.08 & 2.26 & 3.49 \\
\hline \multicolumn{11}{|l|}{ Variety } \\
\hline PBW-343 & 262.18 & 266.04 & 40.71 & 41.31 & 37.17 & 37.09 & 4.44 & 4.51 & 6.71 & 6.81 \\
\hline PBW-502 & 278.66 & 283.55 & 41.94 & 42.67 & 38.30 & 38.22 & 4.42 & 4.80 & 7.19 & 7.32 \\
\hline SEm \pm & 3.88 & 4.66 & 0.63 & 0.72 & 0.57 & 0.65 & 0.66 & 0.79 & 0.73 & 1.02 \\
\hline $\mathrm{CD}$ at $5 \%$ & 12.67 & 15.19 & N.S & N.S & N.S & N.S & 2.15 & 2.58 & 2.38 & 3.33 \\
\hline \multicolumn{11}{|c|}{ Sulphur level kg/ha } \\
\hline 0 & 237.31 & 241.01 & 39.40 & 40.02 & 35.98 & 35.88 & 40.24 & 40.87 & 60.96 & 61.91 \\
\hline 20 & 289.94 & 294.45 & 42.51 & 43.24 & 38.82 & 38.92 & 49.17 & 49.93 & 74.42 & 75.58 \\
\hline 40 & 284.01 & 288.91 & 42.06 & 42.71 & 38.40 & 38.16 & 48.16 & 48.99 & 73.38 & 74.64 \\
\hline S.Em \pm & 3.51 & 4.56 & 1.01 & 0.70 & 0.92 & 0.63 & 0.59 & 0.77 & 0.63 & 0.92 \\
\hline $\mathrm{CD}$ at $5 \%$ & 10.10 & 13.13 & 2.91 & 2.03 & 2.66 & 1.83 & 1.71 & 2.23 & 1.81 & 2.65 \\
\hline
\end{tabular}


Yield is the result of coordinated inter play of growth characters and yield attributes. Grain and straw yield were significantly influenced by the different moisture regimes. Highest grain yield was recorded under moisture regime of 1.2 IW/CPE ratio. This might be due to adequate moisture availability, which contributed to better growth parameters and yield attributes.

Productivity of crop collectively determined by vigor of the vegetative growth and yield attributes. Better vegetative growth coupled with higher yield attributes resulted in higher grain and straw yields.

Lowest grain yield was recorded under 0.6 IW/CPE due to poor moisture supply during the period of growth. Poor moisture supply during the critical stages reduced the yield attributes and resulted in poor grain and straw yields during 2013-14 and 2014-15.

The similar results were reported by Khola et al., (1989), Parihar and Tripathi (1990); Patel and Upadhyay (1973); Kumar et al., (1994); Kumar et al., (1995); bandyopadhyay (1997), Khatri et al., (2001), Behara et al., (2002).

Among the cultivars of wheat included in experiment, PBW 502 has been found more promising in comparison to PBW 343 to provide higher yield attributes as well as yield during both of years. The variation in growth development and yield of varieties might be due to their genetic characteristics. Similar finding in respect to varieties were also reported by Brijkishor (1998).

Application of sulphur increased leaf area, tillering and ear number/plant and other yield attributes. The greater dry matter accumulation, number of ear, ear length, number of grains per ear and 1000 seed weight (yield attributes) were recorded significantly higher with $20 \mathrm{~kg}$ S/ha application over the control during both the years. Grain yield and straw yield were also significantly influenced by sulphur levels. Similar results were found by Chaudhary et al., (2003); Jasim (2011); Siaudinis and Lazauskas (2012).

Thus, it can be concluded that an appropriate sulphur dose of wheat crop was found to be $20 \mathrm{~kg} \mathrm{~S} / \mathrm{ha}$ in 1.0 IW/CPE ratio + PBW-502 treatment combination. The 1.0 IW/CPE ratio was the most suitable moisture regimes for higher productivity of wheat the variety PBW 502 is most suitable for higher productivity of different varieties of wheat. Sowing of wheat crop with 1.0 IW/CPE ratio with the variety PBW 502 may be most economical. An appropriate sulphur dose of wheat crop was found to be $20 \mathrm{~kg} \mathrm{~S} / \mathrm{ha}$. The uptake of NPK and $\mathrm{S}$ by wheat crop was found to be higher in $1.0 \mathrm{IW} / \mathrm{CPE}$ ratio + PBW-502 with $20 \mathrm{~kg}$ $\mathrm{S} /$ ha treatment combination.

\section{References}

Anonymous (2013). Progress Report 2012-2013. Directorate of Wheat Research, Karnal, India pp.1.

Bandyopadhyay, P.K. (1997). Effect of irrigation schedule on evapo-transpiration and water use efficiency of winter wheat (Triticum asetivum. L). Indian J. Agron.42 (1): 90-93.

Behera, B.; Sharma, H. C. and Panda, P. K. (2002). Effect of plant population and sulphur levels on root growth, seed yield and moisture use efficiency of mustard varieties under rainfed conditions. Indian Journal of Soil Conservation; 30(2):161165.

Brijkishor (1998). To assess the performance of newly developed strains of wheat under zero tillage condition with varying nitrogen levels. M.Sc. (Ag.) thesis submitted to N.D.U.A \& T., Kumarganj, Faizabad.

Chaudhary, P. D.; Jat, R. S.and Sharma, H. S. (2003). Interaction effect of phosphorus, sulphur and PSB inoculation on growth, yield and nutrient uptake of wheat. Annals 
of Agricultural Research; 24(1):12-16.

Dubey, Y.P. and Sharma, S.K. (1996).Effect of irrigation and fertilizers on growth, yield and nutrient uptake of wheat. Indian $J$. Agron., 41 (1): 48-51.

Fazal, M. and Sisodia, D. S. (1989).Effect of sulphur and phosphorus on growth, nutrients and oil content in soybean and their residual effect on wheat crop.Annals of Agricultural Science (Cairo); 34(2):915924.

Jasim, A. A. (2011). Role of sulfur and quality of irrigation water on some properties of calcareous soil and growth of wheat (Triticum aestivum). Diyala Agricultural Sciences Journal; 3(1):51-60.

Khatri, R.S.; Goel, A.C. and Malik, P.K. (2001).Water use and application efficiency in bed flat sowing of wheat in rice-wheat system under different irrigation level. Crop Res.21 (2): 20-23.

Khola, O.P.S.; Rao, D.S.; Ram Mohan; Singh, H. and Faroda, A.S. (1989). Response of late sown dwarf wheat to irrigation and fertility levels. Indian J. Agron. 34 (1): 114-116.

Kumar, A., Sharma, D.K. and Sharma, H.C. (1995).Response of wheat (T. aestivumL.) To irrigation and nitrogen in sodic soils. Indian J. Agron., 40 (1): 38.42.

Kumar, A.; Sharma, D.K. and Sharma, H.C. (1994). Growth, yield and water use efficiency of wheat ( $T$. aestivum L.) As influenced by irrigation and nitrogen in sodic soils. Indian J. Agron. 39 (2): 220224.

Limon, Ortega, A:, Sayre, K.D. and Franciss CA(2000) wheat water and nitrogen use efficiency in bed planting system in north west Maxico Indian J. Agron. 92 (2): 303309

Liu BaoCun; SunMingDe; Wu Jing and Huang DeMing. (2002).Effect of interaction between nitrogen and sulphur on wheat growth and its nutrient uptake. Acta Agriculture Boreali-Sinica; 17(3):90-93.

Parihar, S.S. and Tiwari, R.B. (2003). Effect of irrigation and nitrogen levels on yield, nutrient uptake and water use of late sown wheat (Triticum aestivum L.). Indian J.Agron.48 (2), 103-107.

Patel, R.M. and Upadhyay, P.N. 1993.Response of wheat (Triticum aestivum) to irrigation under varying levels of nitrogen and phosphorus. Indian J. Agron.38 (1): 113115.

Rehman, M.A.; Karim, A.J.M.S.; Haque, M.M. and Eqashira, K. (2000).Effect of irrigation and nitrogen fertilization on plant growth and root characteristics of wheat on a clay terrace soil of Bangladesh. J. Faculty of Agric. 45 (1): 301-308.

Siaudinis, G. And Lazauskas, S. (2012). The impact of nitrogen and sulphur on spring wheat productivity and their contents in grain. Scientia Agriculture Bohemica43 (3):95-103. 40.

Singh, D. K.; Agarawal, R.L. and Ahuja, K.N. (1998).Response of wheat varieties to different seeding dates for agro climatic conditions of Agra region. Annals of Agricultural Research 19(4), 496-498.

Yadav, G.L. and Verma, J.K. (1991).Effect of irrigation regime, nitrogen and zinc fertilization on growth and yield of late sown wheat ( $T$. aestivum). Indian $J$. Agron.36:50-56.

\section{How to cite this article:}

Nareshmani Pandey, Sanjay Kumar, Ghanshyam Singh and Singh, R.A. 2017. Effect of Sulphur Nutrient and Moisture Regimes on Growth and Productivity of Wheat (Triticum aestivum L.) Varieties. Int.J.Curr.Microbiol.App.Sci. 6(9): 3623-3628. doi: https://doi.org/10.20546/ijcmas.2017.609.445 